\title{
Challenges in Implementing Biodiversity Policy in Sub-Saharan Africa Region
}

\author{
Jemal Mohammed \\ Crop and Horticulture Biodiversity Directorate, Ethiopian Biodiversity Institute, Addis Ababa, Ethiopia \\ Email address: \\ jemalm781@gmail.com \\ To cite this article: \\ Jemal Mohammed. Challenges in Implementing Biodiversity Policy in Sub-Saharan Africa Region. American Journal of Biological and \\ Environmental Statistics. Vol. 6, No. 2, 2020, pp. 24-30. doi: 10.11648/j.ajbes.20200602.12
}

Received: February 13, 2020; Accepted: February 27, 2020; Published: May 29, 2020

\begin{abstract}
The sub-Saharan Africa is, geographically, the area of the continent of Africa that lies south of the Sahara. According to the United Nations, it consists of all African countries that are fully or partially located south of the Sahara. The region is the less developed regions in the world, where the poorest people who are most vulnerable to biodiversity loss live, are also regions where threats to biodiversity are the highest. Also, the region was rich in high genetic diversity, even though there are a lot of factor that limit the implementation of biodiversity policy to the region. The aim of this review was to collect literature for different factor that limit the implementation of biodiversity policy to the region. Among different factor that affect the implementing of biodiversity policy in sub-Sahara Africa, deforestation is one of the major environmental problems in sub-Saharan Africa. According to World Bank report in 2007, the share of forest area in SSA has declined from 29.3\% in 1990 to $26.1 \%$ in 2007. The other factor is expansion of Agriculture which, directly leads to the loss of the habitats displaced by crop and pasture lands patchy conversion patterns lead to the fragmentation of existing forest, and hence to a reduction in the number and abundance of species that can be supported on unconverted land. The next factor is war and conflict which is common in sub-Sahara Africa. War greatly reduces accessibility and increases the logistical difficulties of protecting the conservation and armed conflicts had a devastating impact on the region's biodiversity. Climate change is an added stress to already threatened habitats, ecosystems and species in Africa, and is likely to trigger species migration and lead to habitat reduction. Up to $50 \%$ of Africa's total biodiversity is at risk due to reduced habitat and other human-induced pressures. Other factors like urbanization, population growth and poverty of sub Saharan region also contribute their effects on the implementation of biodiversity policy. Therefore, it will be good make conducive environment before implementing biodiversity policy to the region to protect this rich biodiversity before losing completely.
\end{abstract}

Keywords: Climate Change, Biodiversity, Sub-sahara, Policy, War, Conflict

\section{Introduction}

Sub-Saharan Africa (SSA) are houses some of the globe's most valuable biodiversity, including charismatic mega fauna, a great diversity of birds, endemic plants and ecological processes. But it also remains one of the most economically impoverished regions of the planet, introducing significant social, political, and economic challenges to conserving biodiversity while enhancing human well-being. The sub-Sahara region is the less developed regions in the world, where the poorest people who are most vulnerable to biodiversity loss live, are also regions where threats to biodiversity are the highest. The Sub-Saharan Africa (SSA) region is a good illustration of such a developing region that is at the forefront of priorities in terms of conservation as well as development needs [1]. The SSA region is also home to almost one-quarter of the biodiversity hotspots, areas around the world where exceptional concentrations of endemic species are undergoing exceptional loss of habitat [2].

Biodiversity is an umbrella term that covers all variety of life on the planet, from the genetic level to terrestrial, freshwater, and marine habitats and ecosystems [3]. Biodiversity is also considered to be a global public good [4]. It is estimated that 25 to $50 \%$ of the pharmaceutical industry relies on genetic diversity for drug developments, and that about US\$ 650 billion per year is derived from genetic resources [5]. The total economic value of pollination 
worldwide amounted to US\$ 153 billion, $9.5 \%$ of the value of the world agricultural production in 2005 [6]. For the entire biosphere, the economic value of 17 ecosystem services has been approximated to be an average of US\$ 33 trillion per year [7].

The increasing effect of humans on the Earth's ecosystems has resulted in its abrupt reduction often referred to as the $6^{\text {th }}$ mass extinction [8] because projected rates of species loss are 100-10,000 times higher than background rates. The main driver of biodiversity loss is land-use change, followed by climate change, nitrogen deposition and biotic exchange. The need to conserve biodiversity has become by now a broadly acknowledged societal goal reflected in international, national and local policies and in a wealth of policy documents educational material and media campaigns. Despite an initial emphasis on moral, ethical or spiritual motivations, often grounded on forceful arguments the dominant view emphasizes nowadays the tangible benefits that biodiversity provides to human society often expressed in economic terms. Indeed, biodiversity is considered the backbone of multiple ecosystem services (erosion control, soil formation, nutrient cycling, pollination, biological control, as well as the regulation of atmospheric composition, climate, water and disturbances) with an average global value of US\$33 trillion per year [7]. Furthermore, biodiversity loss represents a major threat to health and food security.

In contrast to the dynamic evolutionary flux that characterizes life our view on biodiversity and ecosystem functioning has been predominantly static trying to conserve biodiversity as it is and preferably as it was [9]. However, the intensity and speed of human alterations to the planet's ecosystems are yielding this view obsolete. Human actions often result in unforeseen evolutionary pressures that trigger fast evolutionary responses, while drastically affecting (depleting) the raw material of short-term evolutionary responses. At the same time, the dismantling and reshuffling of existing biotic communities, caused by the combination of habitat, climate and biotic changes, results in the ongoing establishment of new communities and co-evolutionary networks for which we lack past analogues [10]. These processes are responsible for the generation, maintenance and (often) erosion of biodiversity in the real (anthropogenic, rapidly changing, increasingly interconnected) world. The need for effective and cost-efficient policies that steer anthropogenic changes towards sustainability places an increasing emphasis on the generation and transference of evolutionary knowledge. Therefore, the objective of this review is to provide literatures about factor affecting the implementation of biodiversity policy in sub-Sahara region.

\section{Literature Review}

\subsection{Deforestation}

Deforestation is one of the major environmental problems in sub-Saharan Africa (SSA). The share of forest area in SSA has declined from $29.3 \%$ in 1990 to $26.1 \%$ in 2007 [11].
Africa has lost about 3.4 million hectares of forest each year in 2000-2010 [12]. The average annual rate of deforestation of the region $(0.8 \%)$ is still by far higher than the world average $(0.15 \%)$ in 1990-2010. Nevertheless, Africa has settled at the bottom in terms of public expenditure on forest sector per hectare [12].

\subsection{Expansion of Agriculture}

The Millennium Ecosystem Assessment (MEA) concluded that as the extensive growth of agriculture is the primary driver of habitat loss in all human dominated landscapes, it is also the primary threat to biodiversity worldwide [13]. By the close of the last century, more than two thirds of Mediterranean forests and temperate forest steppes, and more than half of all temperate broad leaf forests, tropical dry forests, grasslands, shrub-lands and savannas had already been converted to agriculture. While the proportion of tropical habitats converted to agriculture is lower the rate of land conversion in tropical regions is much greater.

While growth in the demand for food in high-income countries has generally stimulated the intensification of agriculture, in low-income countries, it has frequently led to extensive growth. More mouths to feed have meant more people farming more land. Specifically, where traditional land tenure and resource access regimes prevail, and where credit markets are poorly developed, increasing demand for food can only be met by land clearance [14]. Agricultural expansion at the expense of habitat for wild living species has been an essential human survival strategy. Moreover, since poor rural households with low expectations of secure future income have been argued to respond by increasing fertility rates [15], the same process has at least the potential to generate a positive feedback between the demand for agricultural land and population growth. A majority of the people in the least developed countries still live in rural areas, and still make a living from the exploitation of natural resources mostly in agricultural systems.

In many of these countries rural population growth rates are still positive and, in some Sub-Saharan African countries (Benin, Burkina Faso, Burundi, Eritrea, Guinea-Bissau, Mauritania and Uganda) are still increasing [16]. In these countries, is whether intensification reduces the rate of habitat loss from that which might be expected due to population growth alone whether intensification is land sparing. One study of the relationship between the change in the energy yield of 23 food crops and the change in per capita crop land area for 124 countries over the period 1979-1999 found that while the per capita area under these food crops decreased in developing countries where large yield increases occurred, the area used to grow other crops increased [17].

\subsection{Urbanization}

Africa has numerous regions with exceptional biodiversity [18] and is dotted with protected areas (PAs) with different levels of protection status. The PAs cover an area of about 4.5 million $\mathrm{km}^{2}$ across the continent. In 2000, Africa was 
sparsely urbanized with only about $500 \mathrm{~km}^{2}$ of urban land within the boundaries of its PAs. In contrast, by 2030, total urban range within $50 \mathrm{~km}$ of PAs on the continent is expected to reach more than $140,000 \mathrm{~km}^{2}$. In mid latitudinal Africa, the nearly 20 -fold increase in urban extent, the largest forecasted proportional increase in the vicinity of PAs across the world, will pose especially acute challenges for governance and management of PAs and the surrounding lands in this region. While large urban centers such as Nairobi, Kenya and Ibadan, Nigeria dominate the continent's urban expansion patterns, the ecological impacts of the smaller cities and towns across Africa are also considerable.

It is often assumed that migration from rural to urban areas and the resulting concentration of populations in cities would ease the pressure on natural habitats. In many parts of SubSaharan Africa, the migration and subsequent concentration of people in urban areas has indeed reduced rural populations, thus leading to reduced rates of deforestation. However, land speculation by wealthy urban residents has also driven helped by lack of land-use planning and control loss and fragmentation of rangelands close to cities and towns in Ethiopia, Kenya, and Uganda [19]. In Western Africa, the increased demand for food in the cities has incentivized farmers to convert forests to agricultural fields to meet this demand [20].

Prominently, there has been significant foreign direct investment (FDI) aimed at land purchases in the continent to help secure food production for urban residents in other parts of the world. Urbanization and economic development also drive expansion of the transportation network, which in turn often fragment habitats. Of particular concern in the context of biodiversity conservation are the road and railroad infrastructure. Across Africa, there are 33 major development corridors, either proposed or already under construction [21]. If and when constructed, the road and railroad infrastructure in current plans would cut through over 400 PAs and could degrade about 2000 more. Furthermore, large scale changes in transportation networks such as the one proposed around the Serengeti may significantly influence future urban expansion patterns potentially increasing the vulnerability of the PAs in that region [22].

Demand for bush meat, a traditional source of animal protein for humans in much of Sub-Saharan Africa is on the rise fuelled by dietary preferences of urban residents that are fashioned by a combination of urbanization and increasedincome effects [23]. It is shown that the high levels of human density, characteristic of urban and peri-urban areas, are negatively correlated with bush meat from ungulates and primates sold in markets [24]. However, the bush meat trade is also linked to rural livelihoods [25].

The negative impacts of urbanization are evidenced in the expanding haloes of deforestation around cities and transportation routes [26]. Such exploitation of natural resources in expanding waves progressively from the most highly valued to less, is observed both in large cities and around smaller settlements. Peri-urban agriculture, though important for food security in many Sub-Saran African countries, can also contribute to loss and degradation of habitats around cities. Environmental degradation spreading out from an urban center can be significantly enhanced in both speed and intensity depending on the state of the transportation network [26].

Influences external to the continent too play significant roles in shaping the impact of the urbanization on the biodiversity and ecosystems. Some of these are financed by FDI (Foreign Direct Investment) from countries outside Africa increasingly from China, India, Malaysia, and Brazil in addition to Europe and the USA that have been historical sources of FDI to the continent. In recent years, investment from another rapidly urbanizing country, China, has been an important source of funding for infrastructure projects in the continent. How to ensure that such investments facilitate industrial diversification and urban development on the continent without accelerating the decimation of Africa's ecosystems is an outstanding challenge. Demand for animal parts as food, as ornament, or medicine has also been on the rise with the increasing levels of income and integration with global markets in those countries where such demand originates. These influences interact with those internal to the continent to shape patterns of, not only urbanization, but also, habitat degradation, loss, and fragmentation [27].

\subsection{Climate Change}

Africa's biodiversity is concentrated in several unique native environments. The Cape Floral Kingdom (fynbos), which occupies only 37,000 square kilometers at the southern tip of Africa, has 7,300 plant species of which 68 percent occur nowhere else in the world [28]. The adjacent Succulent Karoo biome contains an additional 4,000 species, of which 2,500 are native [29]. These two floral biodiversity hot spots occur in winter rainfall regions and would be threatened by a shift in rainfall seasonality. For instance, a reduction in winter rainfall or an increase in summer rainfall would alter the fire regime that is critical to the life cycle in the fynbos. Other important floral regions affected by global warming include Madagascar, the mountains of Cameroon, and the island-like Afromontane habitats that stretch from Ethiopia to South Africa at altitudes above about 2,000 meters [30]. Montane centers of biodiversity are particularly threatened by increases in temperature because many contain isolated plant populations with no possibility of migration.

Africa occupies about one-fifth of the global land surface and contains about one-fifth of all known species of plants, mammals, and birds in the world, as well as one-sixth of amphibians and reptiles [31]. Climate change has already affected the marine animals of Africa. Coral reefs in the Indian Ocean experienced massive bleaching in 1998, with over 50 percent mortality in some regions [32]. Damage to coral reef systems has far reaching implications for fisheries, food security, tourism and overall marine biodiversity. On land, animal biodiversity in Africa is concentrated in the savannas and tropical forests. Loss or alterations of terrestrial habitats by climate change will likely impact these species. 
Even though, few studies have been done on how climate change will affect terrestrial animals in Africa, but those that have been done demonstrate the potential extent of its impact. For example, climate change of the magnitude predicted for the twenty first century could alter the range of African antelope species [33]. World antelope biodiversity more than 90 percent of the 80 species is concentrated in Africa [34].

Climate change is an added stress to already threatened habitats, ecosystems and species in Africa, and is likely to trigger species migration and lead to habitat reduction. Up to $50 \%$ of Africa's total biodiversity is at risk due to reduced habitat and other human-induced pressures [35]. Savanna vegetation have been identified as highly vulnerable to the effects of climate change [36]. During the last decades, the encroachment of woody plants has already affected savannas. Woody plants are often unpalatable to domestic livestock. Observed expansions in tree cover in South Africa have been attributed to increased atmospheric $\mathrm{CO}_{2}$ concentration or nitrogen deposition. In the western Sahel, however, a 20\% decline in tree density and a significant decline in species richness across the Sahel have been observed for the second half of the twentieth century and attributed to changes in temperature and rainfall variability [37].

While short-term responses of ecosystems in African biomes are typically driven by water availability and fire regimes, in the longer-term African biomes appear highly sensitive to changes in atmospheric $\mathrm{CO}_{2}$ concentrations [36]. A potential shift in competitive advantage from heat-tolerant $\mathrm{C} 4$ grasses to $\mathrm{C} 3$ trees which better benefit from high $\mathrm{CO}_{2}$ concentrations produces to the risk of abrupt vegetation shifts at the local level [38]. The effect may be further enhanced by a positive feedback loop: Trees are expected to accumulate enough biomass under elevated atmospheric $\mathrm{CO}_{2}$ concentrations to recover from fires shading out $\mathrm{C} 4$ grass production and contributing to lower severity of fires, which further promotes tree growth. High rainfall savannas can be replaced by forests in less than 20-30 years [39]. However, forests are also at risk from changes in temperature and precipitation. If extreme weather conditions increase, forests may shrink at the expense of grasses [39]. Despite persistent uncertainties pertaining to these mechanisms and thresholds marking tree mortality, increases in extreme droughts and temperatures pose risks of broad scale climate-induced tree mortality [40].

Ocean ecosystems Aquatic ecosystems globally respond sensitively to the effects of climate change. Consequent risks include the decline in key protein sources and reduced income generation because of decreasing fish catches. Freshwater ecosystems are affected by droughts and associated reductions in nutrient influxes as river inflow is temporarily reduced [41]. Furthermore, increasing freshwater demand in urban areas of large river basins may lead to reduced river flows, which may become insufficient to maintain ecological production, meaning that freshwater fish populations may be impacted [42]. Ocean ecosystems respond to altered ocean conditions with changes in primary productivity, species distribution and food web structure.

\subsection{War and Conflict}

War and violent conflict impact biodiversity conservation in many areas of the world [43]. Much of the world's biodiversity is located in volatile regions where wide spread poverty, political instability and resource competition foment violent conflict on a regular basis [44]. The impacts of conflicts on biodiversity tend to vary considerably, from cases of persistent detrimental effects [45], to scenarios where conflicts reduce human caused threats on biodiversity [46].

War may also reduce the ability of conservation agencies to respond to increased threats. Most obviously, risks to person and place fundamentally alter the calculus of conservation, often limiting management activities [47]. War greatly reduces accessibility and increases the logistical difficulties of protecting the conservation estate [48]. Moreover, funds to support biodiversity conservation may disappear in times of conflict [49]. These impacts on conservation capacity can carry over to post-war periods as displaced populations in need and extractive industries may operate in the absence of regulation and conservation infrastructure [50].

Armed conflicts in the Central African Republic have had a devastating impact on the country's biodiversity. Deforestation from slash and burn agriculture and firewood collection by IDPs fleeing conflict from 1996-1997 in the capital city of Bangui has had significant impact on biodiversity. Conflict in the continually insecure northern part of the country has led to a drop in the elephant population and extinction of an estimated 10,000 rhinoceros. The greatest impact on biodiversity conservation opportunities is the withdrawal of foreign assistance and funding. A poor economic situation led to conflict in the country. Ecotourism could play an important role in economic development [51]. In other case Liberia's civil war led many rural people to hunt a wide array of threatened species to meet basic dietary needs [52].

\subsection{Poverty}

The relationship between biodiversity and poverty largely knows 16 determinants, characterizing socio-economic context, ecosystems and production processes. Market integration, access to capital, management skills and productivity divide all cases into two types of resource-use system: market-oriented and capital-driven, or subsistenceoriented and poverty-driven. How these determinants influence biodiversity and poverty also depends on crosscutting factors, such as population density and growth, ecosystem sensitivity to degradation, governance, and policies on poverty alleviation and biodiversity protection. Policy interventions may shift negative trends towards a more positive direction, making them policy driven.

\subsection{Population Growth}

Population growth is recognized as an indirect driver of 
biodiversity loss, as human demands for resources like food and fuel play a key role in driving biodiversity degradation. This happens primarily through the conversion of ecosystems to food production. Household demographic factors, such as household size, have important implications for resource consumption, with rapid increases in household numbers associated with loss in biodiversity [53]. Population size, growth and density are often regarded as important factors in explaining the loss of species [54]. Over exploitation and habitat loss as a result of population and other pressures is likely to contribute to a high risk of extinction of plants and animals. This is especially true in parts of the world where people are heavily dependent on them for livelihoods.

Areas of rapid population growth overlay those with high numbers of threatened and vulnerable plant species. Habitat loss is generally greatest where population density is highest, and regions rich in endemic species have higher than average population densities and population growth rates [55]. This is true in many parts of Asia and Africa where people and threatened species are often concentrated within the same localities [56]. The number of threatened species is likely to rapidly increase in regions where human population growth rates are high, as the demands for resources of a growing population are predicted to increase in these regions [56] Habitat loss appears to be the most significant threat to biodiversity, and current trends and projections show that land use is and will remain the most prominent driver of biodiversity and ecosystem deterioration [56]. According to the Millennium Ecosystem Assessment, major habitats including forests, grasslands and coastal zones have been heavily impacted by human activities leading to degradation [13]. Population growth may contribute to the degradation of ecosystems when wilderness is converted to agricultural land to meet the needs of increasing human populations. Agricultural land expansion is the most dominant driver for habitat loss, which, combined with unsustainable forest management, contributes to the greatest cause of species moving closer towards extinction [13].

\section{Conclusion}

The sub-Sahara region was one of the world richest biodiversity regions. However due to factor like, expansion of deforestation, expansion of Agriculture, climate change, urbanization, war, poverty and fast growth of population, the region have declined its rich biodiversity. These problems make difficult to the states to implement biodiversity conservation policy properly. Therefore, is better avoiding these problems before implementing biodiversity policy to protect the biological resource of the region.

\section{References}

[1] Fisher, B. and Christopher, T., 2007. Poverty and biodiversity: measuring the overlap of human poverty and the biodiversity hotspots. Ecological economics, 62 (1), pp. 93-101.
[2] Myers, N., Mittermeier, R. A., Mittermeier, C. G., Da Fonseca, G. A. and Kent, J., 2000. Biodiversity hotspots for conservation priorities. Nature, 403 (6772), p. 853.

[3] TEEB. 2010. The Economics of Ecosystems and Biodiversity. Mainstreaming the Economics of Nature: A Synthesis of the Approach, Conclusions and Recommendations of TEEB. Malta: Progress Press.

[4] Rands, M. R., Adams, W. M., Bennun, L., Butchart, S. H., Clements, A., Coomes, D., Entwistle, A., Hodge, I., Kapos, V., Scharlemann, J. P. and Sutherland, W. J., 2010. Biodiversity conservation: challenges beyond 2010. science, 329 (5997), pp. 1298-1303.

[5] TEEB. 2008. The economics of ecosystem and biodiversity.

[6] Gallai, N., Salles, J. M., Settele, J. and Vaissière, B. E., 2009. Economic valuation of the vulnerability of world agriculture confronted with pollinator decline. Ecological economics, 68 (3), pp. 810-821.

[7] Costanza, R., d'Arge, R., De Groot, R., Farber, S., Grasso, M., Hannon, B., Limburg, K., Naeem, S., O'neill, R. V., Paruelo, J. and Raskin, R. G., 1997. The value of the world's ecosystem services and natural capital. nature, 387 (6630), pp. 253-260.

[8] Barnosky, A. D., Matzke, N., Tomiya, S., Wogan, G. O., Swartz, B., Quental, T. B., Marshall, C., McGuire, J. L., Lindsey, E. L., Maguire, K. C. and Mersey, B., 2011. Has the Earth's sixth mass extinction already arrived? Nature, 471 (7336), pp. 51-57.

[9] Grant, R. M., Lama, J. R., Anderson, P. L., McMahan, V., Liu, A. Y., Vargas, L., Goicochea, P., Casapía, M., GuaniraCarranza, J. V., Ramirez-Cardich, M. E. and MontoyaHerrera, O., 2010. Preexposure chemoprophylaxis for HIV prevention in men who have sex with men. New England Journal of Medicine, 363 (27), pp. 2587-2599.

[10] Williams, J. W., Jackson, S. T. and Kutzbach, J. E., 2007. Projected distributions of novel and disappearing climates by 2100 AD. Proceedings of the National Academy of Sciences, 104 (14), pp. 5738-5742.

[11] World Bank. 2010. Millennium Development Goals. World Bank Publishers, Washington DC.

[12] FAO. 2010. Food and Agriculture Organization of the United Nations. Global Forest Resources Assessment 2010. FAO Forestry Paper 163. Rome.

[13] Assessment, M. E., 2005. Ecosystems and human well-being (Vol. 5, p. 563). Washington, DC: Island press.

[14] Bulte, E. H. and Horan, R. D., 2003. Habitat conservation, wildlife extraction and agricultural expansion. Journal of Environmental Economics and Management, 45 (1), pp. 109-127.

[15] Dasgupta P. 2001 An Inquiry in to Well-Being and Destitution (Oxford:ClarendonPress).

[16] World Bank. 2013 World Data Bank: Health Nutrition and Population Statistics (http://databank.worldbank.org/data/views/ variable Selection /select variables. As px? Source =health nutrition-andpopulation-statistics).

[17] Ewers, R. M., Scharlemann, J. P., Balmford, A. and Green, R. E., 2009. Do increases in agricultural yield spare land for nature? Global Change Biology, 15 (7), pp. 1716-1726. 
[18] Mittermeier, R. A., Myers, N., Mittermeier, C. G. and Robles, G., 1999. Hotspots: Earth's biologically richest and most endangered terrestrial ecoregions. CEMEX, SA, Agrupación Sierra Madre, SC.

[19] Flintan F. 2011 Broken lands: Broken lives? Causes, Processes and Impacts of Land Fragmentation in theRangelands of Ethiopia, Kenyaand Uganda Research Report (Nairobi: Regional Learning andAdvocacy Programme (REGLAP)) p 15915.

[20] Parnell, S., Schewenius, M., Sendstad, M., Seto, K. C. and Wilkinson, C., 2013. Urbanization, biodiversity and ecosystem services: challenges and opportunities. Springer, Dordrecht.

[21] Laurance, W. F., Sloan, S., Weng, L. and Sayer, J. A., 2015. Estimating the environmental costs of Africa's massive "development corridors". Current Biology, 25 (24), pp. 32023208 .

[22] Estes, A. B., Kuemmerle, T., Kushnir, H., Radeloff, V. C. and Shugart, H. H., 2012. Land-cover change and human population trends in the greater Serengeti ecosystem from 1984-2003. Biological Conservation, 147 (1), pp. 255-263.

[23] Brashares, J. S., Golden, C. D., Weinbaum, K. Z., Barrett, C. B. and Okello, G. V., 2011. Economic and geographic drivers of wildlife consumption in rural Africa. Proceedings of the National Academy of Sciences, 108 (34), pp. 13931-13936.

[24] Fa, J. E., Olivero, J., Farfán, M. Á., Márquez, A. L., Duarte, J., Nackoney, J., Hall, A., Dupain, J., Seymour, S., Johnson, P. J. and Macdonald, D. W., 2015. Correlates of bushmeat in markets and depletion of wildlife. Conservation Biology, 29 (3), pp. 805-815.

[25] Trends, W. A., 2014. Bush meat and the future of protein in West Africa. A Newsletter Published by ACET (The African Centre for Economic Transformation), 9 (2).

[26] Abernethy, K., Maisels, F. and White, L. J., 2016. Environmental issues in central Africa. Annual Review of Environment and Resources, 41, pp. 1-33.

[27] McDonald, K., Bosshard, P. and Brewer, N., 2009. Exporting dams: China's hydropower industry goes global. Journal of environmental management, 90, pp. S294-S302.

[28] Russell, G. G., 1987. Preliminary floristic analysis of the major biomes in southern Africa. Bothalia, 17 (2), pp. 213-227.

[29] Cowling, R. M., Rundel, P. W., Desmet, P. G. and Esler, K. J., 1998. Extraordinary high regional-scale plant diversity in southern African arid lands: subcontinental and global comparisons. Diversity and Distributions, pp. 27-36.

[30] Mace, G. M., Balmford, A. and Ginsberg, J. R., 1998. Conservation in a changing world (No. Sirsi) i9780521634458).

[31] Siegfried, W. R. 1989. Preservation of species in southern African nature reserves. In: Biotic Diversity in Southern Africa: Concepts and Conservation [Huntley, B. J. (ed.)]. Oxford University Press.

[32] Spalding, M., Spalding, M. D., Ravilious, C. and Green, E. P., 2001. World atlas of coral reefs. Univ of California Press.

[33] Hulme, P. E., 1996. Herbivory, plant regeneration, and species coexistence. Journal of Ecology, 84 (4), pp. 609-615.
[34] Macdonald, D. (ed.). 1987. The Encyclopaedia of Mammals. Equinox Press.

[35] Boko, M., Niang, I., Nyong, A., \& Vogel, C., et al. (2007). Africa. In M. L. Parry, O. F. Canziani, J. P. Palutikof et al. (Eds.), Climate change 2007: Impacts, adaptation and vulnerability. Contribution of Working Group II to the Fourth Assessment Report of the Intergovernmental Panel on Climate Change (pp. 433-467). Cambridge: Cambridge University Press.

[36] Midgley, G. F. and Thuiller, W., 2011. Potential responses of terrestrial biodiversity in Southern Africa to anthropogenic climate change. Regional Environmental Change, 11 (1), pp. 127-135.

[37] Gonzalez, P., Tucker, C. J. and Sy, H., 2012. Tree density and species decline in the African Sahel attributable to climate. Journal of Arid Environments, 78, pp. 55-64.

[38] Higgins, S. I. and Scheiter, S., 2012. Atmospheric CO 2 forces abrupt vegetation shifts locally, but not globally. Nature, 488 (7410), pp. 209-212.

[39] Bond, W. J. and Parr, C. L., 2010. Beyond the forest edge: ecology, diversity and conservation of the grassy biomes. Biological conservation, 143 (10), pp. 2395-2404.

[40] Allen, C. D., A. K. Macalady, H. Chenchouni, D. Bachelet, N. McDowell, and M. Vennetier. "Kitzberger, T., Rigling, A., Breshears, DD, Hogg, EH (Ted), Gonzalez, P., Fensham, R., Zhang, Z., Castro, J., Demidova, N., Lim, JH, Allard, G., Running, SW, Semerci, A., Cobb, N., 2010. A global overview of drought and heat-induced tree mortality reveals emerging climate change risks for forests. For. Ecol. Manage. 259, 660-684. doi: 10.1016/j. foreco. 2009.09. 001." Monitoring Seasonal and Secondary Succession Processes in Deciduous Forests using Near-Surface Optical Remote Sensing and Wireless Sensor Networks 13 (2016): 85.

[41] Ndebele-Murisa, M. R., Musil, C. F. and Raitt, L., 2010. A review of phytoplankton dynamics in tropical African lakes. South African Journal of Science, 106 (1-2), pp. 13-18.

[42] McDonald, R. I., Green, P., Balk, D., Fekete, B. M., Revenga, C., Todd, M. and Montgomery, M., 2011. Urban growth, climate change, and freshwater availability. Proceedings of the National Academy of Sciences, 108 (15), pp. 6312-6317.

[43] McNeely, J. A. ed., 2001. Global strategy on invasive alien species. IUCN.

[44] Hanson, T., Brooks, T. M., Da Fonseca, G. A., Hoffmann, M., Lamoreux, J. F., Machlis, G., Mittermeier, C. G., Mittermeier, R. A. and Pilgrim, J. D., 2009. Warfare in biodiversity hotspots. Conservation Biology, 23 (3), pp. 578-587.

[45] Dudley, Joseph P., and Michael H. Woodford. "Bioweapons, Biodiversity, and Ecocide: Potential Effects of Biological Weapons on Biological Diversity: Bioweapon disease outbreaks could cause the extinction of endangered wildlife species, the erosion of genetic diversity in domesticated plants and animals, the destruction of traditional human livelihoods, and the extirpation of indigenous cultures." BioScience 52, no. 7 (2002): 583-592.

[46] (Program on Forests (2011) Forests, fragility and conflict. Washington. $\mathrm{http}: / / w w w . p r o f o r . i n f o / s i t e s /$ profor. info/files/FRAGILE\%20FOREST_Final_WebRes.pdf. Accessed 14 Oct 2013. 
[47] Hart, T., Hart, J., Fimbel, C., Fimbel, R., Laurance, W. F., Oren, C., Struhsaker, T. T., Rosenbaum, H. C., Walsh, P. D., Razafindrakoto, Y. and Vely, M., 1997. Conservation and civil strife: two perspectives from Central Africa. Conservation Biology, 11 (2), pp. 308-314.

[48] Plumptre, A. J., Masozera, M. and Vedder, A., 2012. The impact of civil war on the conservation of protected areas in Rwanda.

[49] McNeely, J. A. and Scherr, S. J., 2003. Ecoagriculture: strategies to feed the world and save wild biodiversity. Island Press.

[50] Gorsevski, V., Kasischke, E., Dempewolf, J., Loboda, T. and Grossmann, F., 2012. Analysis of the impacts of armed conflict on the Eastern Afromontane forest region on the South Sudan-Uganda border using multitemporal Landsat imagery. Remote Sensing of Environment, 118, pp. 10-20.
[51] http://www.worldwildlife.org/bsp/publications/search.cfm?pu bno $=141$.

[52] Wolkomir, R. and Wolkomir, J., 1992. Caught in the cross-fire. International Wildlife, 22 (1), pp. 5-11.

[53] Liu, J., Daily, G. C., Ehrlich, P. R. and Luck, G. W., 2003. Effects of household dynamics on resource consumption and biodiversity. Nature, 421 (6922), pp. 530-533.

[54] Cincotta, R. P. and Gorenflo, L. J., 2011. Introduction: Influences of Human Population on Biological Diversity. In Human Population (pp. 1-9). Springer, Berlin, Heidelberg.

[55] Cincotta, R. P. and Engelman, R., 2000. Nature's place. Population Action International.

[56] Vié, Hilton-Taylor and Stuart. 2010. Williams, J. W. and Jackson, S. T., 2007. Novel climates, no-analog communities, and ecological surprises. Frontiers in Ecology and the Environment, 5 (9), pp. 475-482. 